\title{
In vitro Antimicrobial Activity of Endodontic Pastes with Propolis Extracts and Calcium Hydroxide: A Preliminary Study
}

\author{
Giovanna Pires da Silva Ribeiro de REZENDE ${ }^{1}$ \\ Luciane Ribeiro de Rezende Sucasas da COSTA $^{2}$ \\ Fabiana Cristina PIMENTA ${ }^{3}$ \\ Daniela Abrão BARONI² \\ ${ }^{1}$ Dental School, Federal University of Goiás, Goiânia, GO, Brazil; \\ School of Health Sciences, University of Brasilia, DF, Brazil \\ ${ }^{2}$ Dental School, Federal University of Goiás, Goiânia, GO, Brazil \\ ${ }^{3}$ Department of Microbiology, Institute of Tropical Pathology and Public Health, \\ Federal University of Goiás, Goiânia, GO, Brazil
}

\begin{abstract}
The purpose of this study was to evaluate the antimicrobial activity of two experimental pastes containing propolis extract associated with calcium hydroxide against polymicrobial cultures collected from 16 necrotic and fistulae root canals in primary molars of 4-8-yearold children of both sexes. The agar-well diffusion technique was used to determine the antimicrobial activity of the following pastes: $11.0 \%$ ethanolic extract of propolis (EEP) + calcium hydroxide; and 11.0\% extract of propolis without ethanol (EP) + calcium hydroxide. EEP, EP and the association of calcium hydroxide and propylene glycol (CHP) was used as the positive control groups, and propylene glycol was used as a negative control group. Friedman and Wilcoxon tests were used to compare the data from the microbial growth inhibition zones $(\mathrm{p}<0.05)$. Paste 1 and Paste 2 showed larger growth inhibition zones against microorganisms from root canal samples than CHP ( $\mathrm{p}=0.021$ and 0.003 , respectively). Paste 2 tended to have larger growth inhibition zones than Paste 1 ( $\mathrm{p}=0.053$ ). The association between propolis and calcium hydroxide was effective in controlling dental infections in vitro.
\end{abstract}

Key Words: antimicrobial activity, propolis, endodontic pathogens.

\section{INTRODUCTION}

Natural products have been used for several years in folk medicine. Apitherapy, or therapy with bee products (e.g. honey, pollen, propolis, fortified honey, herb honey, etc), is an old tradition that has been revitalized in recent research (1). Their beneficial effects allied to the current worldwide "back to nature" trend have led to greater attention being paid to these products (2).

Propolis is a resinous material that honeybees (Apis mellifera L.) collect from various plant species and mix with wax and other substances (3). Scientific research has revealed its antioxidant, antibacterial, antifungal, antiviral, antiinflammatory, anti-tumor and immunomodulating properties (4). Studies on propolis applications have increased because of its therapeutic and biological properties $(5,6)$. Current research involving propolis in dentistry spans many fields and highlights its antimicrobial and antiinflammatory activities, particularly in cariology, oral surgery, pathology, periodontics and endodontics (5,7-9).

Calcium hydroxide is an excellent therapeutic option in endodontics when the clinical situation requires the use of a pulp-capping agent and intracanal medication. This material has been extensively used in dentistry because of its ability to stimulate mineralization and its excellent antimicrobial action (10).

However, the use of calcium hydroxide in the pulp therapy of primary teeth remains a controversial 
issue. Although a systematic review with meta-analysis failed to prove the superiority of one technique or material over another, when considering endodontics for children (11), the effective action of calcium hydroxide in pulpotomies of primary teeth depends on a correctly diagnosed pulpal status. Indeed, calcium hydroxide pastes in primary tooth pulpectomies are rapidly absorbed into the root canal. Faria et al. (12) confirmed the antibacterial action of a calcium hydroxide paste $\left(\right.$ Calen $\left.^{\circledR}\right)$ as an intracanal dressing in human primary tooth root canals with pulp necrosis and apical periodontitis.

Different paste vehicles can change the speed of dissociation and diffusion of calcium hydroxide hydroxyl ions. According to Estrela et al. (13), 'oily vehicles' become an issue if a calcium hydroxide paste is used as an intracanal medicament because oily substances have low solubility in water and do not allow immediate availability of the hydroxyl ions released from calcium hydroxide. Thereby, a less effective antimicrobial action is expected. Otherwise, oily vehicles could be an option when calcium hydroxide is used as an obturation agent.

One could consider associating calcium hydroxide with propolis in order to add all beneficial biological properties of propolis, particularly its antiinflammatory, immunomodulating, antibacterial, antifungal and antiviral properties $(1,5)$ to those of calcium hydroxide. Moreover, as an oily substance, propolis may promote low-speed dissociation and diffusion when used as a component in an endodontic paste for primary teeth. It is important for endodontic compounds to accompany the physiological resorption of primary teeth. The association of propolis with calcium hydroxide could aggregate the benefits of each material. However, propolis should not jeopardize the antimicrobial activity of calcium hydroxide.

In order to verify whether this association could present adequate antimicrobial activity, this preliminary study aimed to evaluate the in vitro antimicrobial activity of two experimental pastes - an ethanolic extract of propolis associated with calcium hydroxide and an extract of propolis without ethanol associated with calcium hydroxide - against polymicrobial cultures collected from necrotic root canals in human primary molars. The tested hypothesis was that the addition of propolis would improve the antimicrobial properties of calcium hydroxide.

\section{MATERIAL AND METHODS}

\section{Samples}

Sixteen 4-8-year-old children of both sexes with primary molars with necrosis and fistulae, seen at the Pediatric Dentistry Clinic of the Dental School of the Federal University of Goiás, Brazil, were selected for this study after the research protocol (Process \#046) had been approved by the local Research Ethics Committee. After placement of the rubber dam/clamp/arch onto the molar to be treated, cavity preparation included the root canals, but did not involve rinsing the canal with antiseptic solutions. Sterile absorbent paper points were introduced into the root canals and left for approximately $1 \mathrm{~min}$. Thereafter, the paper points were removed from the canals and placed in a transport medium containing brain heart infusion (BHI) in a reduced atmosphere. The tube was closed hermetically and processed at the Medical Bacteriology Laboratory of the Institute of Tropical Pathology and Public Health of the Federal University of Goiás. The microorganisms that grew in the medium were stored.

\section{Test Products}

The products used in the present study were two samples of Brazilian commercial propolis - 11.0\% Apis Flora ${ }^{\circledR}$ ethanolic extract of propolis (EEP) and $11.0 \%$ Propomax $^{\circledR}$ extract of propolis without ethanol (EP) (Apis Flora, Ribeirão Preto, SP, Brazil); calcium hydroxide powder $(\mathrm{CH})$ (Biodinâmica, Ibiporá, PR, Brazil); and propylene glycol (Alexfarma, Goiânia, GO, Brazil). Two pastes were evaluated: Paste 1: EEP + calcium hydroxide; Paste 2: EP + calcium hydroxide. Both pastes were prepared with toothpaste consistency.

EEP, EP and calcium hydroxide + propylene glycol (CHP) were used as positive control groups, and propylene glycol was used as a negative control group. There was no conflict of interest involving the researchers and the manufacturers.

\section{Antimicrobial Activity Assay}

Antimicrobial activity of the experimental pastes against the root canal samples was determined in duplicate by the agar-well diffusion technique. The inoculum was prepared with an overnight culture of root canal 
samples and adjusted to $0.5 \mathrm{McF}$ arland standard turbidity, corresponding to approximately 18 colony forming units per milliliter $(\mathrm{cfu} / \mathrm{mL})$. First, $0.5 \mathrm{~mL}$ of inoculum was transferred to thioglycolate plus $0.2 \%$ agar-agar and then placed in an anaerobic jar. After $24 \mathrm{~h}, 10 \mathrm{~mL}$ of BHI plus $5.0 \%$ of yeast extract plus $0.1 \%$ hemin was poured into 16 Petri dishes and left to set. Subsequently, $5 \mathrm{~mL}$ of BHI was inoculated with $2 \mathrm{~mL}$ of the root canal inoculum poured on top and then placed again in an anaerobic jar. Equidistant wells $(5 \mathrm{~mm}$ in diameter and $4 \mathrm{~mm}$ deep) were bored into the agar using a sterile cork borer and the wells were completely filled with the test products. The plates were left at room temperature for $2 \mathrm{~h}$ and then incubated at $37^{\circ} \mathrm{C}$ for $24 \mathrm{~h}$ in anaerobiosis. Antimicrobial activity was determined by measuring the diameters of the polymicrobial growth inhibition zones.

\section{Statistical Analysis}

A statistical analysis was performed using Friedman and Wilcoxon tests to compare the data from the growth inhibition zones using the software SPSS 10.0 (SPSS Inc., Chicago, IL, USA), with a level of significance of $\mathrm{p}<0.05$.

\section{RESULTS}

The growth inhibition zones against each root canal sample as well as their mean and standard deviation are shown in Table 1. Paste 1 showed larger inhibition zones than EP $(p=0.002)$ and CHP $(p=0.021)$. There was no statistically significant difference between Paste 1 and EEP ( $p=0.10)$. Paste 2 also had higher antimicrobial activity than $\mathrm{EEP}(\mathrm{p}=0.08), \mathrm{EP}(\mathrm{p}=0.001)$ and CHP $(\mathrm{p}=0.003)$. EEP presented higher antimicrobial activity than EP $(\mathrm{p}=0.014)$. Paste 1 and Paste 2 showed statistically significant differences from $\mathrm{CHP}(\mathrm{p}=0.021$ and $\mathrm{p}=0.003$, respectively). In addition, Paste 2 presented larger growth inhibition zones than Paste 1 $(\mathrm{p}=0.053)$.

\section{DISCUSSION}

There is no scientific evidence for the existence of an effective material for pulp therapy in primary teeth (11). This study demonstrated that two experimental pastes with propolis and calcium hydroxide were able to inhibit the growth of a pool of microorganisms collected from necrotic root canals of primary teeth.

In the same way as permanent teeth, endodontic infections in primary teeth are of polymicrobial nature, with the development of microbial interactions (14). The predominant microorganisms in pulpitis and dentoalveolar abscess are Prevotella, Porphyromonas, Fusobacterium, and Peptostreptococcus spp (2). Pazelli et al. (15) detected anaerobic microorganisms in $96.8 \%$, and streptococci in $96.7 \%$, of 31 root canals of primary teeth with necrotic pulp and periapical lesions. Thus, an antimicrobial substance for root canal disinfection should act against anaerobic bacteria and streptococci.

Seeking for a useful material against endodontic infections in primary teeth, the present study tested the antimicrobial action of a commercial brand of propolis containing a standardized pool of propolis from different Brazilian regions. Even though the antimicrobial activity of propolis changes according to the region

Table 1. Antimicrobial activity of tested products against polymicrobial cultures (diameters of microbial growth inhibition zones in millimeters).

\begin{tabular}{|c|c|c|c|c|c|}
\hline $\begin{array}{c}\text { Root } \\
\text { canal } \\
\text { samples }\end{array}$ & Paste 1 & Paste 2 & EEP & EP & CHP \\
\hline 1 & 11 & 18 & 15 & 8 & 10 \\
\hline 2 & 10 & 11 & 6 & 6 & 11 \\
\hline 3 & 11 & 12 & 6 & 5 & 11 \\
\hline 4 & 13 & 20 & 15 & 13 & 14 \\
\hline 5 & 11 & 12 & 6 & 6 & 14 \\
\hline 6 & 18 & 16 & 20 & 15 & 11 \\
\hline 7 & 17 & 18 & 15 & 14 & 14 \\
\hline 8 & 12 & 12 & 8 & 9 & 10 \\
\hline 9 & 17 & 20 & 15 & 13 & 12 \\
\hline 10 & 15 & 14 & 15 & 13 & 11 \\
\hline 11 & 18 & 20 & 20 & 20 & 11 \\
\hline 12 & 16 & 16 & 15 & 15 & 12 \\
\hline 13 & 11 & 10 & 10 & 8 & 10 \\
\hline 14 & 16 & 17 & 17 & 17 & 14 \\
\hline 15 & 10 & 11 & 6 & 6 & 10 \\
\hline 16 & 11 & 11 & 8 & 8 & 11 \\
\hline Mean & 13.56 & 14.88 & 12.31 & 11.00 & 11.63 \\
\hline SD & 3.03 & 3.65 & 5.07 & 4.56 & 1.54 \\
\hline
\end{tabular}

Paste $1=11.0 \%$ ethanolic extract of propolis (EEP) + calcium hydroxide; Paste $2=11.0 \%$ extract of propolis without ethanol $(\mathrm{EP})+$ calcium hydroxide $\mathrm{CHP}=$ calcium hydroxide + propylene glycol. 
from where it is collected (17), the same commercial brand proved to be effective in vitro against Grampositive and Gram-negative bacteria and Candida albicans (18).

By testing a mixture of propolis and calcium hydroxide against a polymicrobial culture extracted from primary tooth root canals, better results were observed than those obtained with calcium hydroxide plus propylene glycol. Calcium hydroxide was chosen because it is well established as an endodontic dressing (10), but its use is still controversial in primary teeth (11). A recent systematic review with meta-analysis, however, reported that calcium hydroxide has limited effectiveness in eliminating bacteria from human root canals when assessed by culture techniques (20). The present study confirmed the reduced in vitro antimicrobial activity of calcium hydroxide, suggesting that its association with propolis can be beneficial.

Differences in the research method as well as in propolis components might have influenced the results of this investigation and other studies. In another study (16), propolis showed high antibacterial activity against Gram-positive cocci (Staphylococcus aureus), but had weak activity against Gram-negative bacteria (Escherichia coli and Pseudomonas aeruginosa) and yeasts (Candida albicans). Furthermore, Jordanian propolis can effectively eliminate Enterococcus faecalis from infected dentin models ex vivo (19). Current studies involving propolis had used different microbiological methods, such as agar dilution, agar well diffusion, agar disc diffusion techniques, as well as several concentrations of the propolis extract, which in general ranged from $11 \%$ to $30 \%$ weight to volume $(4,6,14,16,18,19)$. Nevertheless, as the present study used standardized propolis and clinical microbial samples, these materials could be further tested in future investigations employing different methods. This is suggested because the agar-well diffusion technique, in spite of having its value recognized and being widely employed in microbiological research, is less accurate than broth tests for this kind of comparative analysis (13).

The role of ethanol in propolis extracts was unclear. According to the present findings, EEP produced significantly larger inhibition zones than EP, but Paste 1 (containing EEP) presented smaller growth inhibition zones (marginally significant) than Paste 2 (containing EP). While the ethanol in EEP aided the diffusion of the substance into the agar, in Paste 1 calcium hydroxide absorbed the ethanol from EEP and reduced its diffusion.

While these in vitro results showed that no experimental substance was able to eliminate all microbial colonies, the knowledge that propolis is biocompatible with the pulp tissue (9) and has antimicrobial action against endodontic pathogens increases its potential indication in dentistry. The association between propolis and calcium hydroxide could aggregate all the benefits of each one, resulting in a better treatment choice for pulpal diseases in primary teeth. However, further studies on its physicochemical properties and other pharmacological and microbiological aspects are necessary in order to support the conduction of clinical trials with this product.

\section{RESUMO}

O objetivo dessa pesquisa foi avaliar a atividade antimicrobiana de duas pastas experimentais, contendo própolis associada a hidróxido de cálcio, contra culturas polimicrobianas coletadas de 16 molares decíduos necrosados e com fístulas extraídos de crianças entre 4 e 6 anos de idade de ambos os sexos. A técnica de difusão em ágar foi utilizada para determinar a atividade antimicrobiana das seguintes pastas: (1) 11,0\% extrato etanólico de própolis + hidróxido de cálcio e (2) 11,0\% extrato de própolis sem álcool + hidróxido de cálcio. A associação de hidróxido de cálcio com propilenoglicol foi utilizada como o grupo de controle positivo (CHP). Testes estatísticos de Friedman and Wilcoxon foram empregados para comparar dados do crescimento das zonas de inibição $(\mathrm{p}<0,05)$. Pasta 1 e Pasta 2 apresentaram zonas de inibição maiores contra os microrganismos coletados dos canais radiculares do que $\mathrm{CHP}$ ( $\mathrm{p}=0,021 \mathrm{e} 0,003$ respectivamente). A Pasta 2 mostrou zonas de inibição um pouco mais largas que a Pasta $1(\mathrm{p}=0,053)$. A associação entre própolis e hidróxido de cálcio foi efetiva no controle de infecções dentárias in vitro.

\section{REFERENCES}

1. Banskota AH, Tezuka Y, Kadota S. Recent progress in pharmacological research of propolis. Phytotherapy Res 2001;15:561-571.

2. Dobrowolski JW, Vohora SB, Sharma K, Shah S, Naqvi SAH, Dandiya PC. Antibacterial, antifungal, antimoebic, antiinflammatory and antipyretic studies on propolis bee products. J Ethnopharmacol 1991;35:77-82.

3. Hu F, Hepburn HR, Li Y, Chen M, Radloff SE, Daya S. Effects of ethanol and water extracts of propolis (bee glue) on acute inflammatory animal models. J Ethnopharmacol 2005; 100:276-283.

4. Kosalec I, Pepeljnjak S, Bakmaz M, Vladimir-Knezevic S. Flavonoid analysis and antimicrobial activity of commercially available propolis products. Acta Pharm 2005;55:423430.

5. Park YK, Koo MH, Ikegaki M, Cury JA, Rosalen PL. Effects 
of propolis on Streptococcus mutans, Actinomyces naeslundii e Staphylococcus aureus. Rev Microbiol. 1998;29:143-148.

6. Sforcin JM, Fernandes JRA, Lopes CAM, Bankova VJ, Funari SRC. Seasonal effect on Brazilian propolis antibacterial activity. J Ethnopharmacol 2000;73:243-249.

7. Ikeno K, Ikeno T, Miyazawa C. Effects of propolis on dental caries in rats. Caries Res 1991;25:347-351.

8. Koo H, Rosalen PL, Cury JA, Park YK, Ikegaki M, Sattler A. Effects of Apis mellifera propolis from Brazilian regions on caries development in desalivated rats. Caries Res 1999;33:393-400.

9. Bretz WA, Chiego DJ, Marducci MC, Cunha I, Custódio A, Shneider LGZ. Preliminary report on the effects of propolis on wound healing in the dental pulp. Naturforsch 1998;53:1045-1048.

10. Estrela C, Holland R. Calcium hydroxide: study based on scientific evidences. J Appl Oral Sci 2003;11:269-282.

11. Nadin G, Goel BR, Yeung CA, Glenny AM. Pulp treatment for extensive decay in primary teeth. Cochrane Database Syst Rev 2003;1:CD003220.

12. Faria G, Nelson-Filho P, Freitas AC, Assed S, Ito IY. Antibacterial effect of root canal preparation and calcium hydroxide paste (Calen) intracanal dressing in primary teeth with apical periodontitis. J Appl Oral Sci 2005;13:351-355.

13. Estrela C, Pécora JD, Souza-Neto MD, Estrela CRA, Bammann LL. Effect of vehicle on antimicrobial properties of calcium hydroxide pastes. Braz Dent J 1999;10:63-72.
14. Kujumgiev A, Tsvetkova I, Serkedjieva Yu, Bankova V, Christov R, Popov S. Antibacterial, antifungal and antiviral activity of propolis of different geographic origin. J Ethnopharmacol 1999;64:235-240.

15. Pazelli LC, Freitas AC, Ito IY, Souza-Gugelmim MCM, Medeiros AS, Nelson-Filho P. Prevalence of microorganisms in root canals of human deciduous teeth with necrotic pulp and chronic periapical lesions. Braz Oral Res 2003;17:367371.

16. Panzeri H, Lara EHG, Pedrazzi V, Gabarra FR, Ito IY. An experimental dentifrice containing propolis: physical, microbiological and clinical evaluations. J Dent Res 1998;77:975.

17. Scheller S, Ilewicz M, Luciack M, Skrobidurska D, Matuga W. Biological properties and clinical application of propolis. Arzneimittrlforschung/Drug Res 1978;28:289-291.

18. Rezende GPSR, Pimente FC, Costa LRRS. Antimicrobial activity of two Brazilian commercial propolis extracts. Braz J Oral Sci 206;5:967-970.

19. Awawdeh L, AL-Beitawi M, Hammad M. Effectiveness of propolis and calcium hydroxide as a short-term intracanal medicament against Enterococcus faecalis: a laboratory study. Aust Endod J 2008;34:1-9.

20. Sathorn C, Parashos P, Messer H. Antibacterial efficacy of calcium hydroxide intracanal dressing: a systematic review and meta-analysis. Int Endod J 2007;40:2-10.

Accepted September 30, 2008 